\title{
A rootless suture and the loss of the roots of a mountain chain: The Variscan belt of NW Iberia
}

\author{
José R. Martínez Catalán ${ }^{\text {a,* }}$, Ricardo Arenas ${ }^{\mathrm{b}}$, Jacobo Abati ${ }^{\mathrm{b}}$, Sonia Sánchez Martínez ${ }^{\mathrm{b}}$, \\ Florentino Díaz García ${ }^{\mathrm{c}}$, Javier Fernández Suárez ${ }^{\mathrm{b}}$, Pablo González Cuadra ${ }^{\mathrm{d}}$, \\ Pedro Castiñeiras ${ }^{\mathrm{b}}$, Juan Gómez Barreiro ${ }^{\mathrm{b}}$, Alejandro Díez Montes ${ }^{\mathrm{e}}$, \\ Emilio González Clavijo ${ }^{\mathrm{e}}$, Francisco J. Rubio Pascual ${ }^{\mathrm{f}}$, Pilar Andonaegui ${ }^{\mathrm{b}}$, \\ Teresa E. Jeffries ${ }^{\mathrm{g}}$, James E. Alcock ${ }^{\mathrm{h}}$, Rubén Díez Fernández ${ }^{\mathrm{a}}$, \\ Alicia López Carmona ${ }^{\mathrm{b}}$ \\ ${ }^{a}$ Departamento de Geología, Universidad de Salamanca, 37008 Salamanca, Spain \\ ${ }^{\mathrm{b}}$ Departamento de Petrología y Geoquímica and Instituto de Geología Económica (CSIC), \\ Universidad Complutense, 28040 Madrid, Spain \\ ${ }^{\mathrm{c}}$ Departamento de Geología, Universidad de Oviedo, 33005 Oviedo, Spain \\ 'Área de Geodinámica Externa, Universidad de León, 24007 León, Spain \\ ${ }^{\mathrm{e}}$ Instituto Geológico y Minero de España, Azafranal, 48, 37001 Salamanca, Spain \\ ${ }^{\mathrm{f}}$ Instituto Geológico y Minero de España, La Calera, 1, 28760 Tres Cantos, Spain \\ ${ }^{\mathrm{g}}$ Department of Mineralogy, The Natural History Museum, London SW7 5BD, UK \\ ${ }^{\mathrm{h}}$ Department of Geosciences, Abington College, Pennsylvania State University, Abington, PA 19001, USA
}

\begin{abstract}
Ophiolites of different Paleozoic ages occur in North-West (NW) Iberia in a rootless suture representing the remnants of the Rheic Ocean. Associated allochthonous terranes in the hanging- and foot-walls of the suture derive from the former margins, whereas the relative autochthon corresponds to the Paleozoic passive margin of northern Gondwana. The Paleozoic tectonic evolution of this part of the circum-Atlantic region is deduced from the stratigraphical, petrological, structural and metamorphic evolution of the different units and their ages. The tectonic reconstruction covers from Cambro-Ordovician continental rifting and the opening of the Rheic Ocean to its Middle to Upper Devonian closure. Then, the Variscan Laurussia-Gondwana convergence and collision is briefly described, from its onset to the late stages of collapse associated with the demise of the orogenic roots.
\end{abstract}

\section{Résumé}

Une suture sans racines et la perte des racines d'une chaîne montagneuse : la chaîne varisque du Nord-Ouest de l'Ibérie. Des ophiolites d'âges différents affleurent dans le Nord-Ouest de l'Ibérie dans une suture sans racines, témoin de l'océan

\footnotetext{
* Corresponding author.

E-mail address: jrmc@usal.es (J.R. Martínez Catalán).
} 
Rhéique. Les terrains alløchtønes sur et søus la suture dérivent de ses deux marges, tandis que l'autøchtøne relatif appartient à la marge passive du Nord de Gondwana. On peut déduire l'évelution des plaques dans cette partie de la région circum-Atlantique à

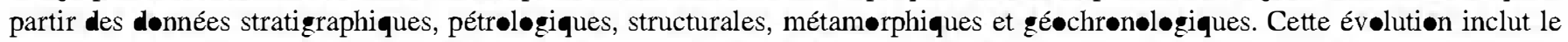
déveløppement d'un rift continental et l'øuverture de l'øcéan Rhéique pendant le Cambrø-Ordøvicien ainsi que sa fermeture au Dévønien møyen à supérieur. On décrit aussi l'évølution de la convergence et cøllisiøn varisque entre Laurussia et Gøndwana, du début jusqu'aux derniers stades d'un efføndrement assøcié à la perte des racines •røgéniques.

Keywerds: Oceanic suture; Rheic Ocean; Variscan evolution; NW Tberia

M॰ts clés : Suture océanique ; Océan Rhéique ; Évolution varisque ; Nord-Ouest de l’Tbérie

\section{Introduction}

The North-West (NW) of the Iberian Massif is located at the hinge zone of the Ibero-Armorican Arc (Fig. 1) and preserves relicts of oceanic domains that once separated the Paleozoic continents [50,51]. A suture occurring in the hanging-wall of a large thrust system is rootless, which makes its interpretation difficult. However, the excellent exposure of the ophiolitic and associated allochthonous terranes permits the establishment of a sequence of emplacement, crosscutting relationships, and metamorphic gradients. In the absence of continental-scale strike-slip shear zones and faults, the Galician-northern Portugal section is redeformable, permitting qualitative palinspastic reconstructions of the Gondwana-Laurussia convergence.

These characteristics make of NW Iberia a key site to unravel the history of the Paleozoic plate evolution of the circum-Atlantic region, and specially that of the Rheic Ocean. This contribution aims to be a synthesis of the research carried out during the last 25 years, when the geology of NW Iberia has been considered in a plate tectonics and terrane perspective. It is based on previously published syntheses $[38,48]$, and on data published elsewhere, being presented here in a very concise way together with the key references.

\section{Geological setting}

The NW Iberian basement consists of plutonic and metamorphic rocks, the latter ranging from very low- to very high-grade. The structural fabric (Fig. 2) alternates linear trends due to thrust faults and narrow folds, with closed structures corresponding to open domes and basins that are a product of late orogenic collapse and extension [48]. A distinction is made between the autochthon and allochthonous terranes. The autochthon consists of a thick metasedimentary and volcanic sequence and includes a foreland thrust belt, the Cantabrian Zone (CZ), and more internal zones where the Paleozoic succession is thicker and rather more complete (Figs. 1 and 2). The autochthonous sequence was deposite in northern Gondwana during the Late Proterozoic and Paleozoic, as indicated by sedimentary and faunal evidence [63] and by detrital zircon age populations [47].

The allochthonous units (Fig. 2) are the remnant of a large nappe stack formed by exotic terranes cropping out in the complexes of Cabo Ortegal, Órdenes, Malpica-Tui, Bragança and Morais. Many are derived from peri-Gondwana, and many bear the imprint of Paleozoic subduction. They include fragments of a Cambro-Ordovician ensialic island arc (upper units) $[8,18,71]$, and distal parts of the Gondwana continental margin (basal units) [44,72]. Ophiolitic units sandwiched between the upper and basal units include remnants of a Cambro-Ordovician back-arc [14,69], possible evidence of Ordovician oceanic crust [60], and suprasubduction type, Early-Middle Devonian ophiolites $[60,70]$.

A thrust sheet several kilometres thick separates the basal, ophiolitic and upper units from the autochthon. It consists of Ordovician and Silurian metasediments and volcanics, and is known variously as the parautochthon [62], the Schistose Domain [26,77], and the lower allochthon [48], this last term describes well the superposition of older over younger rocks, the imbricate character, and the large displacement involved. The lower allochthon has stratigraphic and igneous affinities with the Iberian autochthon [26,77], and represents a distal part of the Gondwana continental margin.

\section{Creation of a peri-Gondwana, ensialic island arc}

The upper allochthonous units occupy the core of the allochthonous complexes (Fig. 2), and two different 


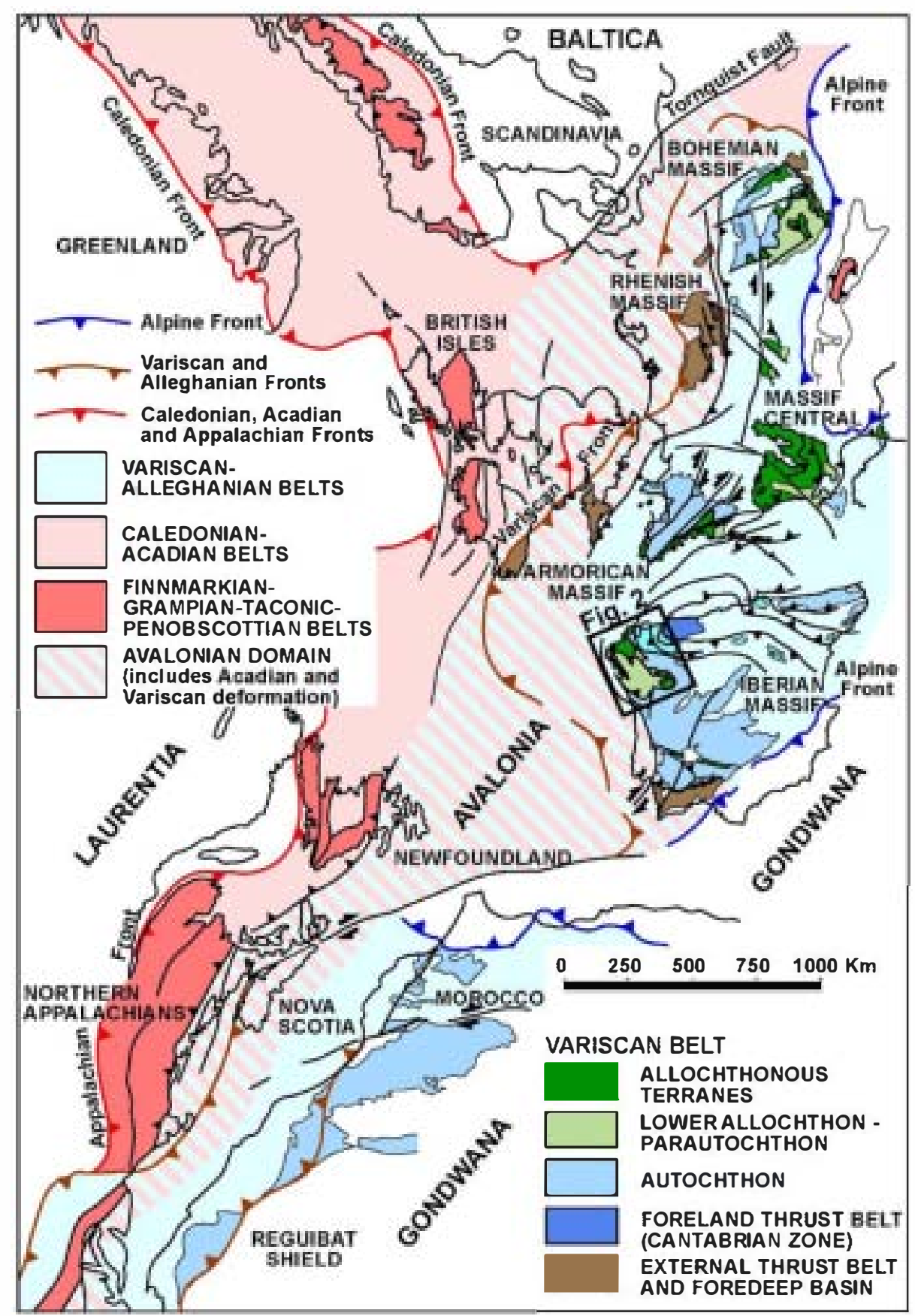

Fig. 1. Location of Iberia in relation to the Paleozoic orogenic belts at the end of Variscan convergence. Modified after Martínez Catalán et al. [46]

Fig. 1. Situation de l'Ibérie par rapport aux ceintures orogéniques paléozoiques, à la fin de la convergence varisque. D'après Martínez Catalán et al. [46], modifiée.

tectonometamorphic histories support a subdivision into intermediate- $P$ upper units above, and high- $P$ and high- $T$ upper units below, but with both groups belonging to the same coherent terrane.

\subsection{Internediate- $\mathrm{P}$ upper units}

These units occupy the highest structural position and consist of terrigenous sediments intruded by Late
Cambrian gabbros and granitoids (Fig. 2). The metamorphic grade ranges from top to bottom between the greenschist and the granulite facies, and shows abrupt changes at extensional detachments $[1,40]$. High-grade rocks occur as large massifs of metaigneous rocks in the Órdenes Complex (Fig. 2). The Monte Castelo gabbro is similar in composition to modern island-arc basalts [8]. The Corredoiras orthogneiss is granodioritic to tonalitic [40], whereas a minor gabbroic 


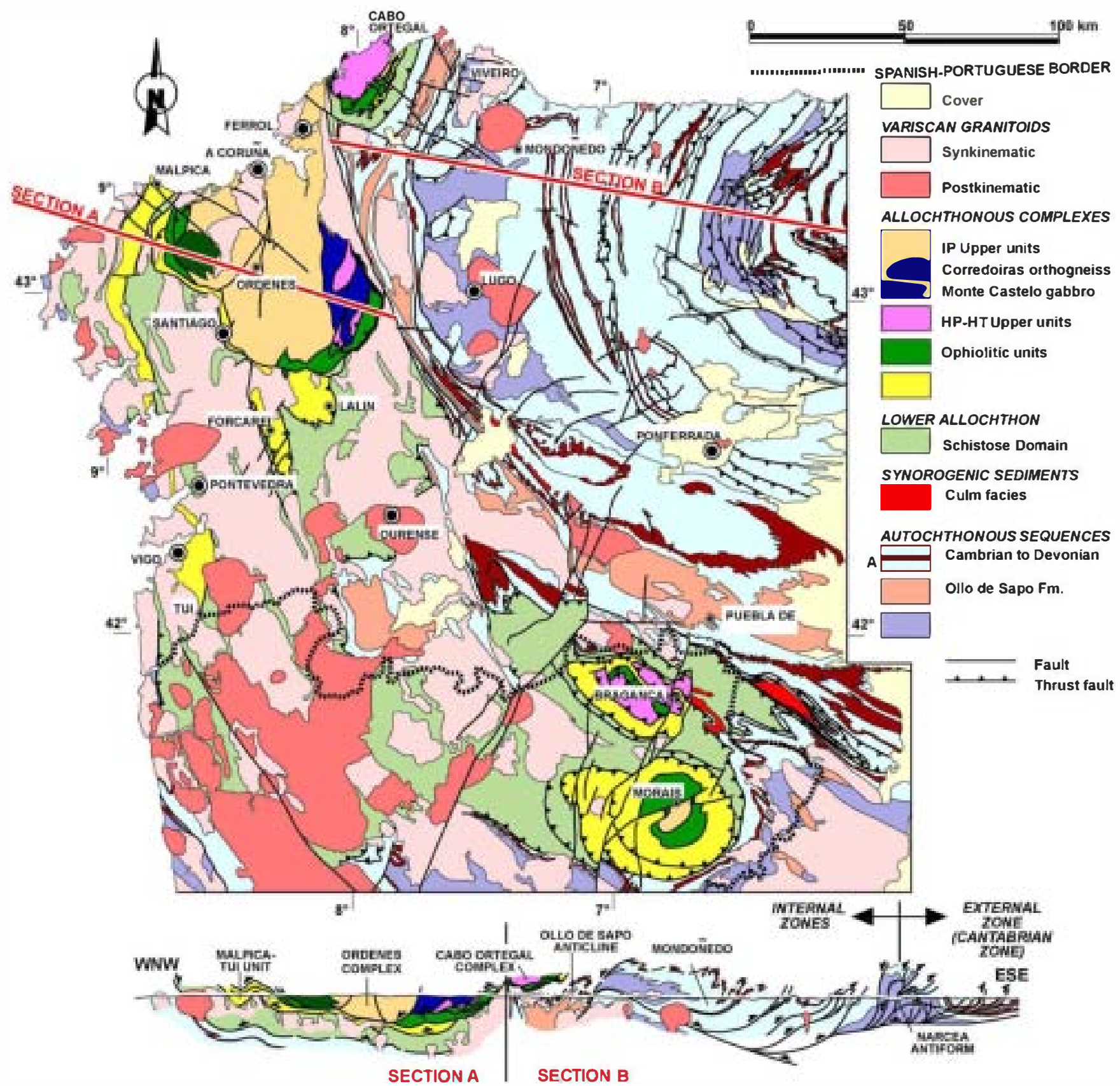

Fig. 2. Geological map and cross sections of North-West (NW) Iberia showing the allochthonous complexes and their units. For location, see Fig. 1. Modified after Dallmeyer et al. [21]

Fig. 2. Carte et coupes géologiques du Nord-Ouest de l'Tbérie montrant les complexes allochtones et leur unités. Pour la situation, voir Fig. 1. D'après Dalhneyer et al. [21], modifiée.

intrusion in the Cabo Ortegal Complex is calc-alkaline and characteristic of a volcanic arc setting [18]. The Corredoiras and Monte Castelo massifs have yielded U$\mathrm{Pb}$ ages of $500 \mathrm{Ma}$ [3], and were affected by granulitefacies shear zones at ca. $480 \mathrm{Ma}[3,5]$.

Mesozonal metasediments represent a Barrovian pile with metamorphic zones ranging from ahnandine to sillimanite [18]. Kyanite replacing andalusite indicates burial after heating, as in the Monte Castelo gabbro and the Corredoiras orthogneiss. Monazites from the sillimanite zone have yielded 493-496 Ma [3], reflecting Cambro-Ordovician, intermediate- $P$ regional metamorphism.

Epizonal metasediments occupy the uppermost structural position and consist of metapelite and greywacke of turbiditic character, with alternations of quartzite and conglomerate. When considered together with the chemistry of the Monte Castelo gabbro, these 
terrigenous sediments, rich in volcanic components, suggest a volcanic arc environment, although the absence of ruly volcanic rocks points to a dissected magmatic arc [31]. Detrital zircon ages in metagreywackes yielded three age populations of $2.5-2.4 \mathrm{Ga}$, 2.1-1.9 Ga and 610-480 Ma [31], establishing an Early-Middle Ordovician maximum depositional age.

\subsection{High-P and high-T upper units}

These units, in the complexes of Bragança, Cabo Ortegal and Órdenes, include paragneisses and ultrabasic metaigneous rocks, but the most characteristic are gamet-clinopyroxene granulites and eclogites retrograded to the amphibolite facies. Gabbros occur in several stages of transformation, from relatively little metamorphosed rocks to coronitic metagabbros, high- $P$ granulites and amphibolites [10]. Subophitic and diabase textures indicate emplacement at relatively shallow levels. The basic rocks are tholeiitic metagabbros with a MORB geochemical signature [35], but geochemical studies of the ultramafic rocks are consistent with generation in an arc setting [71].

$\mathrm{U}-\mathrm{Pb}$ data in metabasic rocks have yielded 520$480 \mathrm{Ma}$, viewed as protolith ages [54], but could also reflect the imprint of nearly contemporaneous metamorphism $[30,32,57]$. However, the high- $P$ granulite and eclogite facies metamorphism is dated, by $\mathrm{U}-\mathrm{Pb}$ and ${ }^{4 \bullet} \mathrm{Ar} /{ }^{39} \mathrm{Ar}$ methods, between 425 and $390 \mathrm{Ma}$ $[30,32,37,54,66,73]$. This event involved subduction [36], and was successively followed by decompression, partial melting, penerative amphibolite-facies mylonitization, which was dated at $390-380 \mathrm{Ma}[20,21,37]$, recumbent folding, and thrusting $[35,42,52]$.

\subsection{The island arc and its fate}

The geochemistry of the plutonic and ultramafic rocks, and the abundance of volcanic components in the metasediments are features consistent with generation of the upper units in an arc setting. The metamorphic evolution of the intermediate- $P$ units points in the same direction, as the $P-T$ paths include isobaric heating related to the intrusion of large plutons, followed by isothermal burial implying crustal thickening $[4,18,40]$. Pressurization in the sillimanite field and a subsequent anticlockwise evolution are linked to active plate margins.

Late Cambrian-Early Ordovician (500-460 Ma) magmatism is widespread in the upper and basal allochthonous units and the autochthon, whereas inherited zircon ages from orthogneisses of all of them are similar, and suggest derivation from the West African craton [57,72]. Derital zircon ages, from lowgrade metasediments in the upper units, also record the major events in NW Africa [31]: this evidence points to a common basement and suggests that the island arc was ensialic (Fig. 3a) and may represent a peri-Gondwanan fragment drifted away to open the Rheic Ocean (Fig. 3b).

The ensialic arc later became involved in the Variscan collision. The Cambro-Ordovician arc-related metamorphism was preserved in the intermediate- $P$ units, but was overprinted by a Silurian-Early Devonian (425-390 Ma) tectonometamorphic event in the high- $P$ and high- $T$ units $[30,32,37]$. This event involved subduction of part of the arc, and resulted from accretion to Laurussia $[37,38,45,48]$ while the Rheic Ocean was still open (Fig. 3c)

\section{Cambro-Ordovician rifting}

\subsection{Paleozoic succession of the autochthon}

Two facts support Early Paleozoic extension:

- the high rates of subsidence deduced from the thick preorogenic succession;

- the voluminous Early Ordovician magmatism.

The dominant sediments are pelite, sandstone, quartzite, and limestone in formations and groups of large lateral extent. Lithologic associations and facies indicate deposition in a passive continental margin, which succeeded the Cadomian Andean-type activity [27]. Differences in thickness in Middle Cambrian to Late Ordovician deposits indicate extensional activity in the margin (Fig. 3b).

Basic to acid volcanism spans from the Cambrian to the Silurian, but is voluminous in the Early Ordovician, when the Ollo de Sapo Formation (Fm.) rocks erupted. It includes a volcaniclastic sequence, rhyolitic-dacitic tuffs, coarse-grained tuffs, welded ignimbrites, and augengneisses [24]. In the Sanabria region, two large volcanic domes have been identified, suggesting that the Ollo de Sapo Fm. includes several volcanic edifices replacing each other along the $570 \mathrm{~km}$ of outcrop [24]: it has yielded Early Ordovician ages of $495-472 \mathrm{Ma}$ [24,53]. Granitoids with ages of 500-465 Ma were intruded in Early Cambrian and Neoproterozoic successions $[15,76]$.

The Ollo de Sapo and the granitic orthogneiss are peraluminous and of calc-alkaline affinity, plotting into the field of the volcanic-arc granites. However, the 
voluminous. Metadacites derived from subaerial lavas and metarhyolites derived from ignimbrite eruptions have been described, as well as syenite intrusions and rhyolitic domes [7,9,33]. An alkaline rhyolite in the Cabo Ortegal Complex yielded an U-Pb age of $475 \mathrm{Ma}$ [77]. That age and the chemistry of the lower volcanic levels compare with the Ollo de Sapo Fm., and the presence of alkaline and basic rocks here are additional arguments for Cambro-Ordovician rifting.

\subsection{The continental rifting in the allochthonous complexes}

Good evidence for Early Paleozoic continental rifting comes from the basal units, which include terrigenous metasediments and igneous rocks. In Portugal, the igneous rocks form a bimodal suite of rhyolitic tuffs, intrusive porphyries, metadiabases and metabasalts [61]. In Galicia, amphibolites of tholeiitic composition, some corresponding to alkali basalts [43], alternate with granitic orthogneisses showing meta- to peraluminous character, and calc-alkaline, alkaline and peralkaline compositions. The latter are A-type granitoids derived from the mantle and are genetically linked to alkali basalts [58]. The orthogneisses yielded $\mathrm{U}-\mathrm{Pb}$ ages of $490-460 \mathrm{Ma}$ [72], and the ensemble reflects the Early Ordovician rifting episode [58] associated with the separation of a peri-Gondwanan fragment and the creation a new continental margin in northern Gondwana (Fig. 3a)

\section{Birth of the Rheic Ocean: witnesses of initial back-arc spreading}

Ophiolitic units occupy an intermediate position in the allochthonous complexes (Fig. 2). The oldest Paleozoic units of ophiolitic affinity include metabasites, metapelitic phyllites and schists, with some serpentinites, metacherts and granitic orthogneisses dated at $497 \mathrm{Ma}$ [14]. The dominant lithology is greenschist-facies metabasites with relict igneous textures indicating a metabasaltic and, to a lesser extent, gabbroic origin. These units are viewed as a thick oceanic sequence of basalts and interbedded pelitic and siliceous sediments, overlying in tectonic contact, serpentinized ultramafic rocks which represent the suboceanic mantle.

The basic rocks include island-arc tholeiites and suprasubduction basalts $[14,69]$. The orthogneisses plot into the field of volcanic arc granitoids. Both mark the opening of a back-arc behind the ensialic periGondwanan island arc during the Latest Cambrian, possibly by slab roll-back linked to oceanic subduction (Fig. 3b). The subsequent spreading of the back-arc created the Rheic Ocean, but these units remained close to Gondwana during its opening, as indicated by their structural position, above the basal units, and with a comparable metamorphic evolution.

\section{Closure of the Rheic Ocean}

Two of the ophiolitic units bear the imprint of oceanic closure in their suprasubduction zone geochemical fingerprints and ages. Moreover, the high- $P$ metamorphism of the basal allochthonous units also points to the closure of the Rheic Ocean.

\subsection{Early Devonian intraoceanic, suprasubduction zone ophiølite}

The Careón Unit is an ophiolitic sequence exposed in the Southeast of the Órdenes Complex. A harzburgitic composition can be inferred for the ulramafic section [22], whereas the gabbroic section is a complex network of multiple intrusions of gabbro, wehrlite, and diabasic to pegmatoid dikes. The metabasites have transitional characteristics between N-MORB and island-arc tholeiites. Their immobile trace element pattern bears a diagnostic negative $\mathrm{Nb}$ anomaly indicating a suprasubduction zone setting $[22,70]$.

$\mathrm{U}-\mathrm{Pb}$ geochronology in two gabbros yielded an age of $395 \mathrm{Ma}$ [22,59], whereas ages of 405-396 Ma were obtained in a gabbro of the equivalent MoraisTalhinhas Unit of the Morais Complex [60], bringing evidence for oceanic crust generation by the Early Devonian. Initial $\varepsilon N d$ values, ranging between +7.1 and +9.2 , obtained for a crystallization age of $395 \mathrm{Ma}$, from $\mathrm{Sm}-\mathrm{Nd}$ isotopic data [59], indicate that the rocks were derived from the depleted mantle reservoir at the time of their formation. Thermobaric estimates on a metamorphic sole unit within the Careón Unit yielded $T \approx 650^{\circ} \mathrm{C}$ and $P \approx 1.15 \mathrm{GPa}$, pointing to a subduction environment for ophiolite imbrication [22]. A wellfoliated amphibolite was dated at $377 \mathrm{Ma}$ [21], interpreted as a cooling age following the metamorphic thermal peak.

\subsection{Metamerphic evolution of the basal units}

Early Variscan, high- $P$ metamorphism in the basal units is demonstrated by eclogites, jadeite-bearing orthogneisses, and blueschists, and is interpreted as the result of subduction $[9,12,13,34,41,64,65,67]$. Peak pressure ranges between $1-1.65 \mathrm{GPa}$ in the Órdenes 
Complex, where $P-T$ gradients along a large recumbent anticline indicate a west-directed polarity (in present coordinates for the subduction [44]). The paleo-dip of the subduction zone has been estimated from the $P-T$ conditions and thermal modeling between 15 and $20^{\circ} \mathrm{C}$ [6]. According to isotopic data, subduction started before $370 \mathrm{Ma}$ ago and ended at ca. $365 \mathrm{Ma}$ [64], being followed by a strong decompression, related to thrusting and tectonic denudation.

\subsection{Landmarks of oceanic closure}

While the Careón and Morais-Talhinhas ophiolites witness a stage of consumption of the Rheic Ocean by intraoceanic subduction (Fig. 3d), subduction of the basal units marks its final closure (Fig. 3e). Deformation and metamorphism progressed eastward and their imprint is reflected in the progressive younging of metamorphic ages from the upper to the basal allochthonous units. In the upper units, 425-390 Ma ages reflect Silurian to Early Devonian compression that created a thick metamorphic pile whose deep parts registere pressures of $1.8 \mathrm{GPa}$ [35,52]. An accretionary wedge, developed at the Laurussia margin (Fig. 3ce), involved thickening, underthrusting and subduction of the upper units. This orogenic event is pre-Variscan and linked to spreading of the Rheic Ocean, rather than Laurussia-Gondwana convergence [38].

Amphibolite facies metamorphism dated at 390$380 \mathrm{Ma}$ was retrogressive in the high- $P$ and high- $T$ upper units, and prograde in the underlying ophiolites, where it reflects the imbrication of oceanic lithosphere during the closure of the ocean. Thrusts formed at that time (ca. $380 \mathrm{Ma}$ ) found the $395 \mathrm{Ma}$ old oceanic lithosphere still hot, and produced metamorphic soles [22]. These thrusts are seen as the first manifestation of early Variscan convergence.

The Cambro-Ordovician ophiolites, that were present during back-arc spreading and which remained on the margin of Gondwana, were the next to enter the accretionary wedge [14]. Afterward, the Gondwana continental margin went into the rench and its edge became subducted between 375 and $365 \mathrm{Ma}[64,72]$. This Late Devonian event, that reached peak pressures of $1.5-1.7 \mathrm{GPa}$, marks the last stage of subductionrelated early Variscan convergence (Fig. 3e).

\section{Variscan collision}

Laurussia-Gondwana convergence continued during the Carboniferous in a collisional regime considered, in a strict sense, to be the Variscan Orogeny.

\subsection{Continuous shortening of the Gondwana continental platform}

The first deformation event $\left(\mathrm{D}_{1}\right)$ produced eastvergent recumbent folds (Fig. 3f) [49]. ${ }^{46} \mathrm{Ar} /{ }^{39} \mathrm{Ar}$ dating of the $S_{1}$ cleavage yielded $359 \mathrm{Ma}$, close to the allochthonous complexes, and $336 \mathrm{Ma}$ to the east [21], showing that shortening was diachronous and younger toward the external zones. $D_{1}$ was the result of the stacked allochthonous terranes pushing against Gondwana as a backstop limited, at its bottom, by a west-dipping sole thrust. Once continental subduction became locked, shortening began in the inner parts of the continental platform, giving rise first to recumbent folds $\left(D_{1}\right)$, and then to large thrust sheets $\left(D_{2}\right)$.

\subsection{Thrust propagation and loss of the suture root}

Three large thrust systems are responsible for the emplacement of the allochthonous complexes. First, the Lalín-Forcarei thrust (LFT) (Fig. 3f) carried the basal units over the lower allochthon. Then, the upper and ophiolitic units moved over the basal units and the lower allochthon, becoming strongly imbricated in a new thrust system, which was developed out-of-sequence (OST) (Fig. 3g). During thrust emplacement, large recumbent folds developed in the upper units $[38,42]$, the ophiolites [14], and the basal units $[23,44]$.

The OST thrusts cut and dismembered the suture, which was steeper [46]. So, a part of it was emplaced over the lower allochthon and subsequently over the autochthon, whereas its deeper, inner parts were left behind, disconnected and hidden (Fig. 3g). Shortly after, the Schistose Domain was emplaced along the lower allochthon thrust (LAT) (Fig. 3g) carrying the allochthonous units piggy-back and using the weak Silurian carbonaceous slates to detach $[26,39]$.

The LFT moved after $346 \mathrm{Ma}$, which was the age of migmatization in one of the basal units [2]. The $S_{2}$ cleavage in the underlying Schistose Domain, dated at $340 \mathrm{Ma}$ [21], was developed during emplacement of the LFT. The LAT is constrained between $340 \mathrm{Ma}$ and $323 \pm 11$ or $317 \pm 15 \mathrm{Ma}$, age of crosscutting Variscan granitoids $[16,55]$. The Mondoñedo basal thrust (MBT) (Fig. 3h) developed subsequently in the autochthon, and more thrusts developed progressively toward the foreland.

\subsection{Extensional collapse, removal of the orogenic roots, and late shortening}

Crustal thickening was followed by thermal relaxation causing increase in temperature and partial melting, 
and facilitating viscous flow that accommodated gravitational extension of the whole crust (Fig. 3i). Extension is marked by a pervasive flat-lying foliation, by thinning and disappearance of previous metamorphic zones at ductile detachments, and by gneiss domes $[11,25]$. Kinematic criteria indicate a noncoaxial component of deformation and extension normal, oblique and parallel to the orogenic trend. High- $T$ and low- $P$ rocks crop out in the domes, accompanied by many Variscan granitoids.

Extension, mid- and lower crustal flow and partial melting were responsible for the disappearance of the orogenic roots and the establishment of a new Moho. The amount of extension was important, given the high strains registered and the abundance of normal detachments. The apparently large displacement shown by the thrusts involved in the suture, ca. $200 \mathrm{~km}$, may, to a large extent, be a consequence of orogenic extension [17], being less important in origin (Fig. 3h). The main phase of collapse and extension occurred between 320 and $310 \mathrm{Ma}$, which is the age of most of the synkinematic granitoids [28].

Extensional collapse was late but not postorogenic, as extension in the internal zones was coeval with the development between 312 and $300 \mathrm{Ma}$ of a thin-skinned foreland thrust belt in the $\mathrm{CZ}$ (Fig. 3j), where large thrusts developed piggy-back, with a total displacement of around $200 \mathrm{~km}$ [56]. Moreover, extensional domes in the internal zones were overprinted by upright folds: these late upright folds $\left(D_{3}\right)$ interfere with early recumbent folds and fold the regional metamorphic isograds. The largest folds nucleated in domes and basins developed previously, although the Lugo (LD) (Fig. 3k) and Sanabria domes developed later [24,48]. Folds are associated with strike-slip ductile shear zones which moved at between 315 and $305 \mathrm{Ma}$ [75], and displaced the suture [48], further contributing to its rootless character.

\section{Summary of terrane dispersal, accretion and continental collision}

The European Variscides are partly situated to the south of Baltica in a reconstruction (Fig. 1) that postdates Carboniferous dextral strike-slip movement between Laurussia and Gondwana [48,74]. Before dextral motion, the Variscan belt was situated more to the upper right corner of Fig. 1 lying perhaps entirely to the South of Baltica. This implies that the Variscides formed by collision of northern Gondwana with eastern Avalonia and Baltica, and further suggests that their ophiolitic units are relicts of the eastern branch of the
Rheic Ocean, also that the upper allochthonous units were accreted to Avalonia and Baltica during the closure of the Tornquist Ocean.

A cartoon map reconstruction of continents and oceans during the Paleozoic, based on Winchester et al. [79] is shown on Fig. 4. Detrital zircon age populations

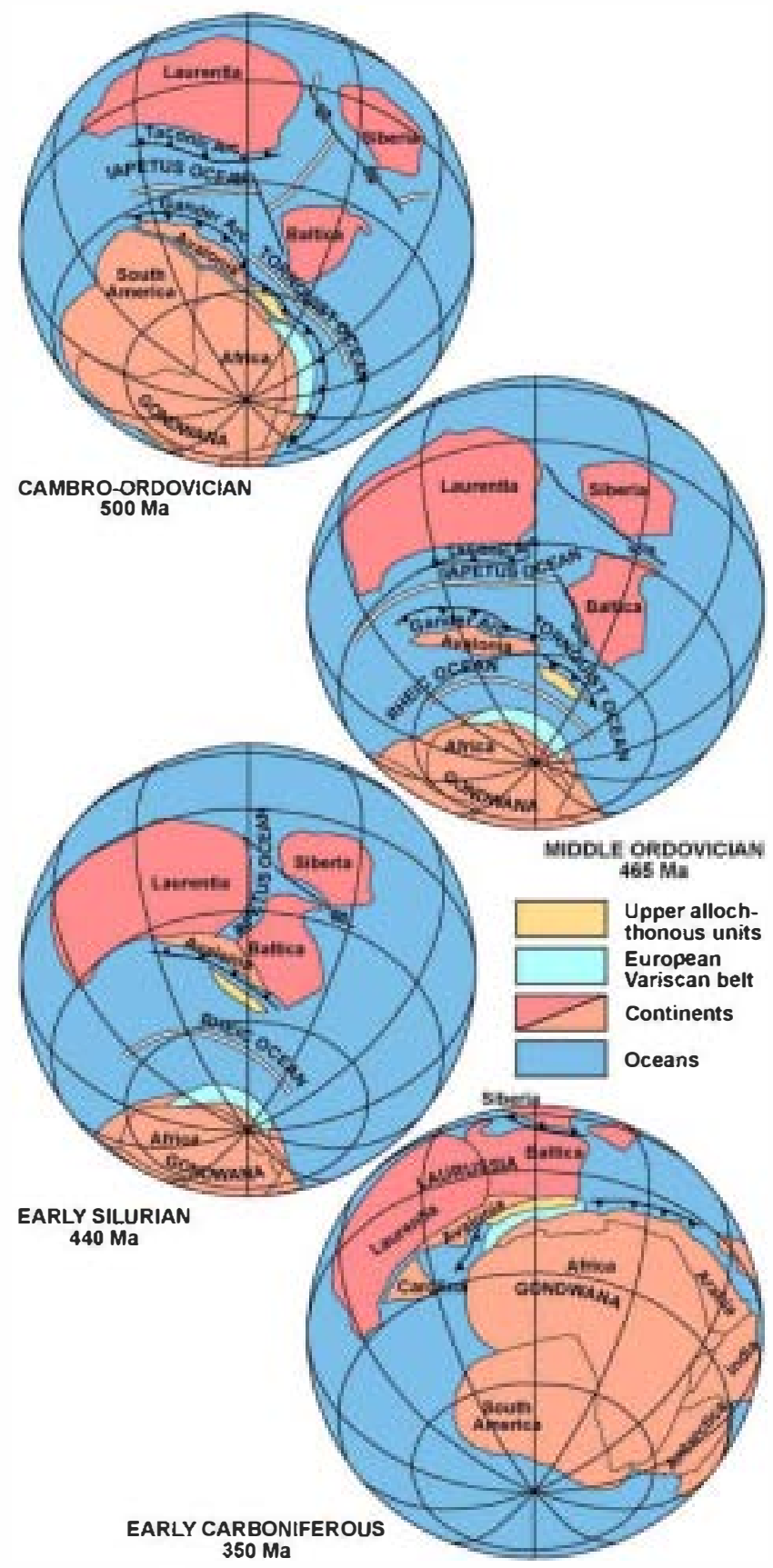

Fig. 4. Distribution of continental masses during the Paleozoic, showing the suggested paleopositions of the European Variscides and the ensialic arc preserved in the upper allochthonous units Modified after Gómez Barreiro et al. and Winchester et al. [38,79].

Fig. 4. Distribution de masses continentales pendant le Paléozoique montrant les positions suggérées du Variscides européennes et de l'arc préservé dans les unités allochtones supérieures. D'après Gómez Barreiro et al. et Winchester et al. [38,79], modifié. 
in Neoproterozoic and Paleozoic sediments of NW Iberia are typical of the West African craton and the Avalonian-Cadomian-Pan-African belts, but also include a Mesoproterozoic population which could suggest proximity to the Amazonian craton [29], or NE Africa [38]. An oceanic terrane dated at 1120-1170 Ma is involved in the NW Iberian suture [68], suggesting the presence of Mesoproterozoic rocks in the northern margin of Gondwana prior to Cambro-Ordovician terrane dispersal. The peri-Gondwana arc preserved in the upper allochthonous units has been placed in the periphery of NW Africa, halfway between the two possible known sources of Mesoproterozoic zircons, in agreement with the apparent lack of zircons of that age [31]. The upper units would represent the lateral equivalent, or a continuation of Avalonia and the Gander Arc where, as in the upper units, separation took place around the Cambro-Ordovician boundary [48,79] and accretion occurred in the Early Silurian [19].

Once separated, the ensialic arc drifted away from Gondwana during the Ordovician, leaving behind the Rheic Ocean, and was in collision with Laurussia during Silurian to Early Devonian times. Although this lithospheric fragment drifted away from Gondwana and later became emplaced on it, the site of derivation probably differs from that of emplacement (Fig. 4). This may explain inconsistencies in the ages of magmatism and metamorphism as rifting, drifting, accretion and collision were likely to have been diachronous along the continental margins.

\section{Discussion: importance of the Rheic Ocean}

Pre-Variscan and Variscan orogenic events in the Iberian Massif are comparable with those in the Armorican, Massif Central and Bohemian massifs. However, the importance of the Rheic Ocean has not always been recognized in central Europe, and other oceanic reahns separating Gondwana-derived microplates have been proposed to account for ophiolites and subduction-related metamorphism. The NW Iberian Peninsula is less affected by large strike-slip shear zones, permitting a qualitative palinspastic reconstruction that yields a simplified interpretation valid for this part of the Variscan belt, and which can shed light on the understanding of other areas.

According to sedimentary and faunal evidence [63], and on the evidence of inherited zircon population ages [47], the Iberian allotochthon was always part of the northern margin of Gondwana. Furthermore, the NW Iberian suture corresponds to a single major ocean, the Rheic, because:
- the protolith ages of the involved ophiolitic units span a time interval of $105 \mathrm{Ma}$, similar to that of existence of the Rheic Ocean [79];

- arc-related magmatism and metamorphism is $125 \mathrm{Ma}$ older than oceanic closure, which supports the Rheic option, because the development of an arc inside the Rheic Ocean, when it was starting to open, is unrealistic. Arc development during the Ordovician was widespread in the Iapetus Ocean [78,79], and correlation of the upper units with an arc occurring outside of Gondwana and facing the Iapetus or Tornquist oceans is much more reasonable (Fig. 3b).

Our model shows the influence of the Rheic Ocean in the Paleozoic evolution of Iberia, an influence that can be extended to other reahns of the Variscan belt. For instance, Woodcock et al. [80] link the Acadian deformation (400-390 Ma) in England and Wales, with subduction of the Rheic Ocean to the north beneath the Avalonian lithosphere. This is coherent with our hypothesis that the arrival of the island arc to the margin of Laurussia was followed by its accretion and partial subduction, dated at $425-390 \mathrm{Ma}$ in the high- $P$ and high-T upper units (Fig. 3c). Woodcock et al. [80] even suggest that the upper allochthonous units of $\mathrm{NW}$ Iberia are the best candidate for the missing segment of the Laurussian margin of England and Wales. However, discrepancies arise conceming the type of subduction of the Rheic lithosphere at $400-380 \mathrm{Ma}$, either flat subduction beneath Laurussia [80], or intraoceanic subduction (Fig. 3d). Assuming large strike-slip displacements between Laurussia and Gondwana $[48,80]$, these differences simply represent slightly different scenarios taking place in areas separated by hundreds or thousands of kilometres.

\section{Acknowledgements}

This work was funded by the projects CGL200404306-C2/BTE and CGL2007-65338-C02/BTE of the Spanish Ministerio de Educación y Ciencia, and is a contribution to the IGCP 497: The Rheic Ocean: Its Origin, Evolution and Correlatives. Two reviewers, J.P. Burg and M. Sintubin, have contributed to improve the manuscript, and their efforts are kindly acknowledged.

\section{References}

[1] J. Abati, Petrología metamórfica y geocronología de la unidad culminante del Complejo de Órdenes en la región de Carballo (Galicia, NW del Macizo Ibérico), Serie Nova Terra 20, 2002, Lab. Xeol. Laxe, A Coruña, Spain, p. 269. 
[2] J. Abati, G.R. Dunning, Edad U-Pb en monacitas y rutilos de los paragneises de la Unidad de Agualada (Complejo de Órdenes, NW del Macizo Ibérico), Geogaceta 32 (2002) 95-98.

[3] J. Abati, G.R. Dunning, R. Arenas, F. Díaz García, P. González Cuadra, J.R. Martínez Catalán, P. Andonaegui, Early Ordovician orogenic event in Galicia (NW Spain): evidence from $\mathrm{U}-\mathrm{Pb}$ ages in the uppermost unit of the Ordenes Complex, Earth Planet. Sci. Lett. 165 (1999) 213-228.

[4] J. Abati, R. Arenas, J.R. Martínez Catalán, F. Díaz García, Anticlockwise $P-T$ path of granulites from the Monte Castelo Gabbro (Órdenes Complex, NW Spain), J. Petrol. 44 (2003) 305-327.

[5] J. Abati, P. Castiñeiras, R. Arenas, J. Fernández-Suárez, J. Gómez Barreiro, J.L. Wooden, Using SHRIMP zircon dating to unravel tectonothermal events in arc environments. The Early Palaeozoic arc of NW Iberia revisited, Terra Nova 19 (2007) 432-439.

[6] J. Alcock, R. Arenas, J.R. Martínez Catalán, Shear stress in subducting continental margin from high-pressure, moderatetemperature metamorphism in the Ordenes Complex, Galicia, NW Spain, Tectonophysics 397 (2005) 181-194.

[7] E. Ancochea, R. Arenas, J.L. Brandle, M. Peinado, J. Sagredo, Caracterización de las rocas metavolcánicas silúricas del Noroeste del Macizo Ibérico, Geociências, Aveiro 3 (1988) 23-34.

[8] P. Andonaegui, J. González del Tánago, R. Arenas, J. Abati, J.R. Martínez Catalán, M. Peinado, F. Díaz García, Tectonic setting of the Monte Castelo gabbro (Ordenes Complex, northwestern Iberian Massif): Evidence for an arc-related terrane in the hanging wall to the Variscan suture, in: J.R. Martinez Catalán, R.D. Hatcher Jr., R. Arenas, F. Díaz García (Eds.), VariscanAppalachian Dynamics: the Building of the Late Paleozoic Basement, Geol. Soc. Am. Spec. Paper 364, 2002, pp. 37-56.

[9] R. Arenas, Evolución petrológica y geoquímica de la unidad alóctona inferior del complejo metamórfico básico-ultrabásico de Cabo Ortegal (Unidad de Moeche) y del Silúrico paraautóctono, Cadena Hercínica Ibérica (NW de España), Corpus Geologicum Gallaeciae 4, Lab. Xeol. Laxe, A Coruña, Spain, 1988, p. 543 .

[10] R. Arenas, J.R. Martínez Catalán, Prograde development of corona textures in metagabbros of the Sobrado window (Ordenes Complex, NW Iberian Massif), in: J.R. Martínez Catalán, R.D. Hatcher Jr., R. Arenas, F. Díaz García (Eds.), Variscan-Appalachian Dynamics: the Building of the Late Paleozoic Basement, Geol. Soc. Am. Spec. Paper 364, 2002, pp. 73-88

[11] R. Arenas, J.R. Martínez Catalán, Low-P metamorphism following a Barrovian-type evolution. Complex tectonic controls for a common ransition, as deduced in the Mondoñedo thrust sheet (NW Iberian Massif), Tectonophysics 365 (2003) 143-164.

[12] R. Arenas, F.J. Rubio Pascual, F. Díaz García, J.R. Martínez Catalán, High-pressure microinclusions and development of an inverted metamorphic gradient in the Santiago Schists (Ordenes Complex, NW Iberian Massif, Spain): evidence of subduction and syncollisional decompression, J. Metam. Geol. 13 (1995) 141-164.

[13] R. Arenas, J. Abati, J.R. Martínez Catalán, F. Díaz García, F.J Rubio Pascual, $P-T$ evolution of eclogites from the Agualada Unit (Ordenes Complex, NW Iberian Massif, Spain): Implications for crustal subduction, Lithos 40 (1997) 221-242.

[14] R. Arenas, J.R. Martínez Catalán, S. Sánchez Martínez, J. Fernández-Suárez, P. Andonaegui, J.A. Pearce, F. Corfu, The Vila de Cruces Ophiolite: A remnant of the early Rheic Ocean in the Variscan suture of Galicia (NW Iberian Massif), J. Geol. 115 (2007) 129-148.

[15] F. Bea, P. Montero, C. Talavera, T. Zinger, A revised Ordovician age for the Miranda do Douro orthogneiss, Portugal. Zircon U$\mathrm{Pb}$ ion-microprobe and LA-ICPMS dating, Geol. Acta 4 (2006) 395-401.

[16] F. Bellido, J.L. Brandle, M. Lasala, J. Reyes, Consideraciones petrológicas y cronológicas sobre las rocas graníticas hercínicas de Galicia, Cuad. Lab. Xeol. Laxe 17 (1992) 241-261.

[17] J.-P. Burg, J. Van Den Driessche, J.P. Brun, Syn- to postthickening extension in the Variscan Belt of western Europe: Modes and structural consequences, Geol. Fr. 3 (1994) 33-5I.

[18] P. Castiñeiras, Origen y evolución tectonotermal de las unidades de O Pino y Cariño (Complejos Alóctonos de Galicia), Lab Xeol. Laxe, Serie Nova Terra, 28, A Coruña, Spain, 2005, p. 279

[19] P.A. Cawood, J.A.M. Van Gool, G.R. Dunning, Collisional tectonics along the Laurentian margin of the Newfoundland Appalachians, in: J.P. Hibbard, C.R. van Staal, P.A. Cawood (Eds.), Current perspectives in the Appalachian-Caledonian Orogen, Geol. Assoc. Canada Spec. Paper 41, 1995, pp. 283 301.

[20] R.D. Dallmeyer, A. Ribeiro, F. Marques, Polyphase Variscan emplacement of exotic terranes (Morais and Bragança Massifs) onto Iberian successions: Evidence from ${ }^{4 \bullet} \mathrm{Ar} /{ }^{39} \mathrm{Ar}$ mineral ages, Lithos 27 (1991) 133-144

[21] R.D. Dallmeyer, J.R. Martínez Catalán, R. Arenas, J.I. Gil Ibarguchi, G. Gutiérrez Alonso, P. Farias, J. Aller, F. Bastida, Diachronous Variscan tectonothermal activity in the NW Iberian Massif: Evidence from ${ }^{40} \mathrm{Ar} /{ }^{3 \boldsymbol{9}} \mathrm{Ar}$ dating of regional fabrics, Tectonophysics 277 (1997) 307-337.

[22] F. Díaz García, R. Arenas, J.R. Martínez Catalán, J. González del Tánago, G. Dunning, Tectonic evolution of the Careón ophiolite (Northwest Spain): a remnant of oceanic lithosphere in the Variscan belt, J. Geol. 107 (1999) 587-605

[23] R. Díez Fernández, J.R. Martínez Catalán, J. Abati Gómez, Recumbent folding in Serra do Galiñeiro (Pontevedra, NW España), Geogaceta 40 (2006) 3-6.

[24] A. Díez Montes, La Geología del Dominio “Ollo de Sapo" en las comarcas de Sanabria y Terra do Bolo, PhD Thesis, Univ Salamanca, Spain, 2006, p. 496.

[25] J. Escuder Viruete, R. Arenas, J.R. Martínez Catalán, Tectonothermal evolution associated with Variscan crustal extension in the Tormes Gneiss Dome (NW Salamanca, Iberian Massif, Spain), Tectonophysics 238 (1994) 1 17-138.

[26] P. Farias, G. Gallastegui, F. González-Lodeiro, J. Marquínez, L.M. Martín Parra, J.R. Martínez Catalán, J.G. de Pablo Maciá, L.R. Rodríguez Fernández, Aportaciones al conocimiento de la litoestratigrafía y estructura de Galicia Central, Mem. Fac Ciências, Univ. Porto, Portugal 1 (1987) 4ll-431.

[27] J. Fernández-Suárez, G. Gutiérrez-Alonso, G.A. Jenner, S.E. Jackson, Geochronology and geochemistry of the Pola de Allande granitoids (northern Spain). Their bearing on the Cadomian/Avalonian evolution of NW Iberia, Can. J. Earth Scien. 35 (1998) 1439-1453.

[28] J. Fernández-Suárez, G.R. Dunning, G.A. Jenner, G. GutiérrezAlonso, Variscan collisional magmatism and deformation in NW Iberia: constraints from $\mathrm{U}-\mathrm{Pb}$ geochronology of granitoids, $\mathrm{J}$. Geol. Soc. Lond. 157 (2000) 565-576.

[29] J. Fernández-Suárez, G. Gutiérrez-Alonso, G.A. Jenner, M.N Tubrett, New ideas on the Proterozoic-Early Paleozoic evolution of NW Iberia: insights from U-Pb detrital zircon ages, Precambrian Res. 102 (2000) 185-206. 
[30] J. Fernández-Suárez, F. Corfu, R. Arenas, A. Marcos, J.R Martínez Catalán, F. Díaz García, J. Abati, F.J. Fernández, U$\mathrm{Pb}$ evidence for a polyorogenic evolution of the HP-HT units of the NW Iberian Massif, Contr. Mineral. Petrol. 143 (2002) 236-253.

[31] J. Fernández-Suárez, F. Díaz García, T.E. Jeffries, R. Arenas, J. Abati, Constraints on the provenance of the uppermost allochthonous terrane of the NW Iberian Massif: Inferences from detrital zircon U-Pb ages, Terra Nova 15 (2003) 138-144.

[32] J. Fernández-Suárez, R. Arenas, J. Abati, J.R. Martínez Catalán, M.J. Whitehouse, T.E. Jeffries, U-Pb chronometry of polymetamorphic high-pressure granulites: An example from the allochthonous terranes of the NW Iberian Variscan belt, in: R.D. Hatcher Jr., M.P. Carlson, J.H. McBride, J.R. Martínez Catalán (Eds.), 4-D framework of continental crust, Geol. Soc. Am. Mem. 200, 2007, pp. 469-488.

[33] G. Gallastegui, L.M. Martín Parra, J.G. de Pablo Maciá, L.R. Rodríguez Fernández, Las metavulcanitas del Dominio Esquistoso de Galicia-Tras-os-Montes: petrografía, geoquímica y ambiente geotectónico (Galicia, NO de España), Cuad. Lab Xeol. Laxe 12 (1988) 127-139.

[34] J.I. Gil Ibarguchi, Petrology of jadeite-metagranite and associated orthogneiss from the Malpica-Tuy allochthon (Northwest Spain), Europ. J. Min. 7 (1995) 403-415.

[35] J.I. Gil Ibarguchi, M. Mendia, J. Girardeau, J.J. Peucat, Petrology of eclogites and clinopyroxene-gamet metabasites from the Cabo Ortegal Complex (northwestern Spain), Lithos 25 (1990) 133-162.

[36] J.I. Gil Ibarguchi, B. Abalos, J. Azcárraga, P. Puelles, Deformation, high-pressure metamorphism and exhumation of ulramafic rocks in a deep subduction/collision setting (Cabo Ortegal, NW Spain), J. Metam. Geol. 17 (1999) 747-764.

[37] J. Gómez-Barreiro, J.R. Wijbrans, P. Castiñeiras, J.R. Martínez Catalán, R. Arenas, F. Díaz García, J. Abati, ${ }^{4} \mathrm{Ar} /{ }^{3 \mathbf{9}}$ Ar laser probe dating of mylonitic fabrics in a polyorogenic terrane of NW Iberia, J. Geol. Soc. Lond. 163 (2006) 61-73.

[38] J. Gómez Barreiro, J.R. Martínez Catalán, R. Arenas, P. Castiñeiras, J. Abati, F. Díaz García, J.R. Wijbrans, Tectonic evolution of the upper allochthon of the Órdenes Complex (northwestern Iberian Massif): structural constraints to a polyorogenic peri-Gondwanan terrane, in: U. Linnemann, R.D. Nance, P. Kraft, G. Zulauf (Eds.), The evolution of the Rheic Ocean: From Avalonian-Cadomian active margin to Alleghenian-Variscan collision, Geol. Soc. Am. Spec. Paper 423, 2007, pp. $315-332$.

[39] E. González Clavijo, J.R. Martínez Catalán, Stratigraphic record of preorogenic to synorogenic sedimentation, and tectonic evolution of imbricate units in the Alcañices synform (northwestern Iberian Massif), in: J.R. Martínez Catalán, R.D. Hatcher Jr., R. Arenas, F. Díaz García (Eds.), Variscan-Appalachian Dynamics: the Building of the Late Paleozoic Basement, Geol. Soc. Am. Spec. Paper 364, 2002, pp. 17-35.

[40] P. González Cuadra, La Unidad de Corredoiras (Complejo de Órdenes, Galicia): Evolución estructural y metamórfica, Serie Nova Terra 33, 2002, Lab. Xeol. Laxe, A Coruña, Spain, p. 254.

[41] A. López Carmona, J. Abati, J. Reche, Metamorphic evolution of the HP/LT Ceán schists (Malpica-Tui Unit, NW Iberian Massif), Geogaceta 43 (2008) 3-6.

[42] A. Marcos, J. Marquínez, A. Pérez-Estaún, J.A. Pulgar, F. Bastida, Nuevas aportaciones al conocimiento de la evolución tectonometamórfica del Complejo de Cabo Ortegal (NW de España), Cuad. Lab. Xeol. Laxe 7 (1984) 125-137.
[43] J.L. Marquínez García, La geología del área esquistosa de Galicia Central (Cordillera Herciniana, NW de España), Mem. Inst. Geol. Min. España 100, 1984, p. 231.

[44] J.R. Martínez Catalán, R. Arenas, F. Díaz García, F.J. Rubio Pascual, J. Abati, J. Marquínez, Variscan exhumation of a subducted Paleozoic continental margin: The basal units of the Ordenes Complex, Galicia, NW, Spain, Tectonics 15 (1996) 106-121.

[45] J.R. Martínez Catalán, R. Arenas, F. Díaz García, J. Abati, Variscan acretionary complex of northwest Iberia: Terrane correlation and succession of tectonothernal events, Geology 25 (1997) 1103-1106.

[46] J.R. Martínez Catalán, F. Díaz García, R. Arenas, J. Abati, P. Castineiras, P. González Cuadra, J. Gómez Barreiro, F. Rubio Pascual, Thrust and detachment systems in the Ordenes Complex (northwestern Spain): Implications for the Variscan-Appalachian geodynamics, in: J.R. Martínez Catalán, R.D. Hatcher Jr., R. Arenas, F. Díaz García (Eds.), Variscan-Appalachian Dynamics: the Building of the Late Paleozoic Basement. Geol. Soc. Am. Spec. Paper 364, 2002, pp. 163-182.

[47] J.R. Martínez Catalán, J. Fernández-Suárez, G.A. Jenner, E. Belousova, A. Díez Montes, Provenance constraints from detrital zircon $\mathrm{U}-\mathrm{Pb}$ ages in the NW Iberian Massif: implications for Paleozoic plate configuration and Variscan evolution, J. Geol. Soc. Lond. 161 (2004) 461-473.

[48] J.R. Martínez Catalán, R. Arenas, F. Díaz García, J. GómezBarreiro, P. González Cuadra, J. Abati, P. Castiñeiras, J. Fernández-Suárez, S. Sánchez Martínez, P. Andonaegui, E. Gónzalez Clavijo, A. Díez Montes, F.J. Rubio Pascual, B. Valle Aguado, Space and time in the tectonic evolution of the northwestern Iberian Massif. Implications for the Variscan belt, in: R.D. Hatcher Jr., M.P. Carlson, J.H. McBride, J.R. Martínez Catalán (Eds.), 4-D framework of continental crust, Geol. Soc. Am. Mem. 200, 2007, pp. 403-423.

[49] $\mathrm{Ph}$. Matte, La structure de la virgation hercynienne de Galice (Espagne), Rev. Geol. Alp. 44 (1968) 1-128.

[50] $\mathrm{Ph}$. Matte, Tectonics and plate tectonics model for the Variscan belt of Europe, Tectonophysics 126 (1986) 329-374.

[51] $\mathrm{Ph}$. Matte, Accretionary history and crustal evolution of the Variscan belt in western Europe, Tectonophysics 196 (1991) 309-337

[52] M.S. Mendia Aranguren, Petrología de la Unidad Eclogítica del Complejo de Cabo Ortegal, (NW de España), Serie Nova Terra 16, 2000, Lab. Xeol. Laxe, A Coruña, Spain, p. 424.

[53] P. Montero, F. Bea, F. González Lodeiro, C. Talavera, M.J. Whitehouse, Zircon ages of the metavolcanic rocks and metagranites of the Ollo de Sapo Domain in central Spain: implications for the Neoproterozoic to Early Palaeozoic evolution of Iberia, Geol. Mag. 144 (2007) 963-976.

[54] B. Ordóñez Casado, D. Gebauer, H.J. Schäfer, J.I. Gil Ibarguchi, J.J. Peucat, A single Devonian subduction event for the HP/HT metamorphism of the Cabo Ortegal complex within the Iberian Massif, Tectonophysics 332 (2001) 359-385.

[55] L.A. Ortega Cuesta, Estudio petrogenético del granito sincinemático de dos micas de A Espenuca (A Coruña), Serie Nova Terra 14, 1998, Lab. Xeol. Laxe, A Coruña, Spain, p. 377.

[56] A. Pérez-Estaún, F. Bastida, J.L. Alonso, J. Marquínez, J. Aller, J. Alvarez-Marrón, A. Marcos, J.A. Pulgar, A thin-skinned tectonics model for an arcuate fold and thrust belt: The Cantabrian Zone (Variscan Ibero-Armorican Arc), Tectonics 7 (1988) $517-537$ 
[57] J.J. Peucat, J. Bernard-Griffiths, J.I. Gil Ibarguchi, R.D. Dallmeyer, R.P. Menot, J. Cornichet, M. Iglesias Ponce de León, Geochemical and geochronological cross-section of the deep Variscan crust: The Cabo Ortegal high-pressure nappe (northwestern Spain), Tectonophysics 177 (1990) 263-292.

[58] C. Pin, L.A. Ortega Cuesta, J.I. Gil Ibarguchi, Mantle-derived, Early Paleozoic A-type metagranitoids from the NW Iberian Massif: Nd isotope and trace-element constraints, Bull. Soc. geol. France 163 (1992) 483-494.

[59] C. Pin, J.L. Paquette, J.F. Santos Zalduegui, J.I. Gil Ibarguchi, Early Devonian suprasubduction zone ophiolite related to incipient collisional processes in the western Variscan Belt: The Sierra de Careón unit, Ordenes Complex, Galicia, in: J.R. Martínez Catalán, R.D. Hatcher Jr., R. Arenas, F. Díaz García (Eds.), Variscan-Appalachian Dynamics: the Building of the Late Paleozoic Basement, Geol. Soc. Am. Spec. Paper 364, 2002, pp. 57-71.

[60] C. Pin, J.L. Paquette, B. Ábalos, F.J. Santos, J.I. Gil Ibarguchi, Composite origin of an early Variscan transported suture: Ophiolitic units of the Morais Nappe Complex (north Portugal), Tectonics 25 (2006) 1-19.

[61] A. Ribeiro, Contribution à l'étude tectonique de Trás-os-Montes Oriental, Mem. Serv. Geol. Portugal 24, 1974, p. 179

[62] A. Ribeiro, J. Munha, R. Dias, A. Mateus, E. Pereira, L. Ribeiro, P. Fonseca, A. Araujo, T. Oliveira, J. Romao, H. Chamine, C. Coke, J. Pedro, Geodynamic evolution of the SW Europe Variscides, Tectonics 26 (2007) 1-24.

[63] M. Robardet, The Armorica "microplate": fact or fiction? Critical review of the concept and contradictory paleobiogeographical data, Palaeogeogr. Palaeoclimatol. Palaeoecol. 195 (2003) 125-148.

[64] J. Rodríguez, M.A. Cosca, J.I. Gil Ibarguchi, R.D. Dalhneyer, Strain partitioning and preservation of ${ }^{4 \bullet} \mathrm{Ar} /{ }^{3 \mathbf{9}} \mathrm{Ar}$ ages during Variscan exhumation of a subducted crust (Malpica-Tui complex, NW Spain), Lithos 70 (2003) 111-139

[65] J. Rodríguez Aller, Recristalización y deformación de litologías supracorticales sometidas a metamorfismo de alta presión (Comple jo de Malpica-Tuy, NO del Macizo Ibérico), SerieNova Terra, 29, 2005, Lab. Xeol. Laxe, A Coruña, Spain, p. 572

[66] F. Roger, Ph. Matte, Early Variscan HP metamorphism in the western Iberian Allochthon: A $390 \mathrm{Ma} \mathrm{U}-\mathrm{Pb}$ age for the Braganca eclogite (NW Portugal), Int. J. Earth Sci. 94 (2005) 173 179.

[67] F.J. Rubio Pascual, R. Arenas, F. Díaz García, J.R. Martínez Catalán, J. Abati, Eclogites and eclogite-amphibolites from the Santiago Unit (Ordenes Complex, NW Iberian Massif, Spain): a case study of contrasting high-pressure metabasites in a context of crustal subduction, in: J.R. Marínez Catalán, R.D. Hatcher Jr., R. Arenas, F. Díaz García (Eds.), Variscan-Appalachian Dynamics: the Building of the Late Paleozoic Basement, Geol. Soc. Am. Spec. Paper 364, 2002, pp. 105-124.
[68] S. Sánchez Martínez, T. Jeffries, R. Arenas, J . Fernández-Suárez, R. García-Sánchez, A pre-Rodinian ophiolite involved in the Variscan suture of Galicia (Cabo Ortegal Complex, NW Spain), J. Geol. Soc., Lond. 163 (2006) 737-740

[69] S. Sánchez Martínez, R. Arenas, P.. Andonaegui, J.R. Martínez Catalán, J.A. Pearce, 2007, Geochemistry of two associated ophiolites from the Cabo Ortegal complex (Variscan belt of northwest Spain), in: R.D. Hatcher Jr., M.P. Carlson, J.H. McBride, J.R. Martínez Catalán (Eds.), 4-D framework of continental crust, Geol. Soc. Am. Mem. 200, 2007, pp. 445-467.

[70] S. Sánchez Martínez, R. Arenas, F. Díaz García, J.R. Martínez Catalán, J. Gómez-Barreiro, J.A. Pearce, Careón Ophiolite, NW Spain: Suprasubduction zone setting for the youngest Rheic Ocean floor, Geology 35 (2007) 53-56.

[71] J.F. Santos, U. Schärer, J.I. Gil Ibarguchi, J. Girardeau, Genesis of pyroxenite-rich peritotite at Cabo Ortegal (NW Spain): geochemical and $\mathrm{Pb}-\mathrm{Sr}-\mathrm{Nd}$ isotope data, J. Petrol. 43 (2002) 17-43.

[72] J.F. Santos Zalduegui, U. Schärer, J.I. Gil Ibarguchi, Isotope constraints on the age and origin of magmatism and metamorphism in the Malpica-Tuy allochthon, Galicia, NW-Spain, Chem. Geol. 121 (1995) 91-103.

[73] J.F. Santos Zalduegui, U. Schärer, J.I. Gil Ibarguchi, J. Girardeau, Origin and evolution of the Paleozoic Cabo Ortegal ultramafic-mafic complex (NW Spain): $\mathrm{U}-\mathrm{Pb}, \mathrm{Rb}-\mathrm{Sr}$ and $\mathrm{Pb}-$ $\mathrm{Pb}$ isotope data, Chem. Geol. 129 (1996) 281-304.

[74] D. Shelley, G. Bossière, A new model for the Hercynian Orogen of Gondwanan France and Iberia, J. Struct. Geol. 22 (2000) 757-776.

[75] B. Valle Aguado, M.R. Azevedo, U. Schaltegger, J.R. Martínez Catalán, J. Nolan, U-Pb zircon and monazite geochronology of Variscan magmatism related to syn-convergence extension in central northern Portugal, Lithos 82 (2005) 169-184.

[76] P.. Valverde-Vaquero, G.R. Dunning, New U-Pb ages for Early Ordovician magmatism in Central Spain, J. Geol. Soc. Lond. 157 (2000) 15-26.

[77] P. Valverde-Vaquero, A. Marcos, P.. Farias, G. Gallastegui, U-Pb dating of Ordovician felsic volcanism in the Schistose Domain of the Galicia-Trás-os-Montes Zone near Cabo Ortegal (NW Spain), Geol. Acta 3 (2005) 27-37.

[78] C.R. van Staal, The northern Appalachians, in : R.C. Selley, L.R.M. Cocks, I.R. Plimer (Eds.), Encyclopedia of Geology, Elsevier, Oxford, 2005, pp. 81-91.

[79] J.A. Winchester, T.C. Pharaoh, J. Verniers, Palaeozoic amalgamation of Central Europe: an introduction and synthesis of new results from recent geological and geophysical investigations, in: J.A. Winchester, T.C Pharaoh, J. Verniers (Eds.), Palaeozoic Amalgamation of central Europe, Geol. Soc. Spec. Publ. 201, 2002, pp. 1-18.

[80] N.H. Woodcock, N.J. Soper, R.A. Strachan, A Rheic cause for the Acadian deformation in Europe. J. Geol. Soc. Lond. 164 (1997) 1023-1036. 